\title{
Heidegger'de Metafizik Eleştirisi olarak Sanat Yapıtı
}

\section{Emrah Akdeniz}

Özet: Bu makalede Heidegger'in metafizik düşünce geleneğine ilişkin eleştirisi, onun sanat yapıtı üzerine yorumları bağlamında tartısmaya açlıyor. Batı metafizik düşüncesinin varolanların Varlığını düşünülemez kılarak, Varlığın hakikatinin üzerini nasıl örttüğünün anlaşılabilmesi için Heidegger'in kadim Yunandaki sanat yapıtına döndüğünü ve batı metafizik geleneğini aşabilmek için sanat aracıllğ̆ıyla bu dönemin Varlık anlayışını ortaya koyduğu gösterilmeye çalışlacaktır. Böylece makale Heidegger'in sanat yapıtını otantik anlamda nasıl ele aldığını vurgulamak suretiyle Varlığın anlamının da nasıl anlaşılması gerektiğini göstermeye çalışacaktır. Anahtar Sözcükler: Sanat yapıtı, hakikat, varlık, varolanlar, geleneksel metafizik düşünce

Abstract: In this paper, Heidegger's criticism of the tradition of metaphysical thinking is opened to discussion in the context of his interpretation of the work of art. In order to understand how Western metaphysical thought conceals the truth of Being by rendering unthinkable the Being of the beings, this paper will attempt to show that Heidegger turns to ancient Greek art and elaborates the ancient Greek understanding of Being through the art of the period in order to transcend the western metaphysical tradition. This paper will also attempt to show how the meaning of Being must be understood by emphasizing how Heidegger treats the work of art in its authentic meaning.

Keywords: Work of art, truth, being, beings, traditional metaphysical thinking

Martin Heidegger sanatı ve sanat yapıtını estetik bir bakış açısından okumaz. Sanat yapıtı onun için Varlığın anlamının açıldığı ve bu bakımdan özne-nesne ikiliğinin ortadan kalktığı bir gerçekleşmeler bütününün ya da ağının adıdır. Sanat yapıtında bir dünya vardır ve metafizik yorum, yapıtı nesne düzeyine indirgeyerek bu dünyayı, başka bir deyişle yapıtta olagelen hakikati gözden kaçırmaktadır. Heidegger sanat yapıtı aracılığıyla, teknolojik çağın tanıdıklaştıran ve alıştıran örtüsü altında kaybolan, uzağında kalınmış ve yabancı bir yaşamın olanağına işaret eder. Bu aynı zamanda sanat yapıtı ve sanat aracılığıyla ortaya çıkan eleştirel ve dönüştürücü bir duruşu da ifade eder. Dolayısıyla Heidegger' in eleştirel düşüncesini ortaya koymanın en temel yollarından birisi de onun, ilk bakışta, sanat felsefesi altında değerlendirilebilir gibi görünen sanat yapıtına ilişkin yorumunu ele almaktan geçer.

Akdeniz, Emrah. (2016). Heidegger'de Metafizik Eleştirisi olarak Sanat Yapıtı. Kilikya Felsefe Dergisi 2. ss. 79-92. 
Heidegger, temel tasarısını oluşturan ve tamamlamadan bıraktığ1 Varlık ve Zaman adlı yapitında sormuş olduğu, metafizik tarihinin gözden kaçırdığı, varlı̆̆ın anlamı sorusunu, düşüncesinin ilerleyen evrelerinde farklı bağlamlar içinde, geliştirdiği kimi yeni kavramlar aracılığıyla tekrar tekrar ele alır. Bu tutumun ilk örneklerini 1935 yılında vermiş olduğu seminerlerden oluşan ve varlığın anlamını Sokrates-öncesi düşüncenin ışığında ele alarak yorumlamaya çabaladığı, varlık düşüncesinde belli bir kırılmanın işaretlerini taşıyan Metafiziğe Giriş adlı metniyle, yine aynı yıllarda vermiş olduğu Sanat Yapıtının Kökeni adlı başlı başına sanata ayrılmış olan konferansın, birçok yorumcunun da belirttiği gibi, oldukça enigmatik görünen metni oluşturur. Her iki metnin ortak özelliği dinleyiciye neredeyse aynı yıllarda ulaşmış olmak dışında varlığın anlamı sorusuna da benzer bir perspektiften yaklaşmış olmalarıdır. Sanat yapıtının kökeni başlıklı metin sanata ayrılmış olmakla birlikte aslında Heidegger' in öncelikli, hatta neredeyse tek derdi olan varlı̆̆ın anlamı sorusu temelinde ilerleyen bir metindir ve bu nedenle de metin, sanat yapitının metafizik tarihinde kökleşerek biçimlenen klasik bir alımlanışını sunmaz; tersine, nesne ve nesneye karşı konumlanarak sanatsal bir deneyimi yaşantılayan özne ikiliğinde temel bulan estetik anlayışa yönelik bir eleştiriyi dillendirir. Estetiğin kalkış noktası olan bu ikili anlayışın temel nedenini Heidegger varlığın anlamı sorusu bağlamında unutulan hakikat kavramına bağlar. Estetikteki eğilim Platon'dan itibaren hakikati, mantığın alanına hapsederek onun güzelle olan bağını kopartmıştır. Bu durumu Heidegger'e göre metafizik tarihinde adım adım izlemek olanaklıdır. Olanın varlığa gelişi, olmakta oluşu, açı̆̆a çıkışı olarak Hakikat, Heidegger' in yorumuna göre Sokrates-öncesi dönemde güzelle henüz ayrışmamıştır. Olanın varlığa gelişi bu dönemde görünüş olarak düşünülmektedir. Yani görünüş belli bir biçime (forma) sahip olmak bakımından

\begin{abstract}
... 1şı̆̆ını olanın olmaklığı olarak Varlıktan alır. Böylece Varlık, oluşunu eidos olarak gerçekleştirir. İdea kendini morphe'ye uydurur. Morphe ve hule'nin birliği olarak sunolon, yani ergon energeia'nın etkinliği içindedir. Bu açığa çıkış kipi ens actu'nun actualitis'i olur. Actualitas gerçeklik olur. Gerçeklik nesnellik olur. Nesnellik de deneyim olur (Heidegger, 2001, s. 79) .
\end{abstract}

Bu gelişim çizgisi içinde etkinliğin kendisi yalnızca güzelin, güzel nesnenin deneyimine indirgenmiş olur. Estetik böylece, Platon'da olduğu gibi, güzeli idealarda geçerliliğini bulan nesnel bir zemin temelinde anlamaya çalışan ya da Kant'ta olduğu gibi güzelin özne bakımından 
koşullarını araştıran düşünsel bir alan olarak hakikati, hakikatin varlıkla ve güzelle olan ayrılmaz bağını gözden kaçırır. Heidegger, sanat yapıtının kökeni sorununu bu üçlü ilişki bağlamında ele alarak metafizik tarihinde gözden kaçırılanı, varlığın anlamını, yani hakikati yorumlar.

Heidegger, sanatı incelediğinde onun temel özelliklerini insan deneyiminin özgül ve yalıtılmış bir alanı olarak değil de Varlığın anlamını açı̆̆a çıkaran olası bir ipucu olarak belirler (Palmer, 1998, s. 397).

$\mathrm{Bu}$, estetikle birlikte bağımsızlaştırılarak öznenin duyu algısına verilen bir güzellik anlayışını tekrar ait olduğu bağlam içinde görme çabası olarak da düşünülebilir. Söz konusu aitlik kendini ilkin Heidegger'in temel kavramlarından birisi olan dünya kavramında gösterir.

\section{Dünya}

Heidegger'in metni üç başlık altında ilerler: Şey ve Yapıt, Yapıt ve Hakikat, Hakikat ve Sanat. İlk başlığın yer aldığı bölümde sanat yapıtının bir estetik nesne olarak alımlanması bağlamında alımlanabilen bir şey olarak yapıtın şeysel olmasının ne anlama gelebileceği tartışılır. Aslında bu bağlamda tartışılan, bir yapıtı yapıt kılanın, onun şey özelliği olup olmadığıdır. Şey' in metafizik tarihi içindeki kavranışları, yapıtın yapıtlığını ön plana getirenin şey olmadığını gösterir. Metafizik tarihinde şey ilkin kimi özellikleri, çevresinde toplayan temel olarak, yani töz olarak düşünülmüştür. Antik Yunan dünyasında buna altta yatarak temel oluşturan anlamında hupokeimenon denmiştir. Bu, zamanla Roma dünyasının Latinceye yapmış olduğu çevirilerle anlamsal olarak dönüşüme uğramış; Hupokeimenon subiectum'a, hupostasis substantia'ya sumbebekos accidens'e dönüşmüştür. Heidegger'e göre tözün özneye, ilineğin yükleme dönüşmesi şey ve yapıt bağlamında yansitma ya da temsil sorununa neden olmuştur. Ortaya çıkan durum, artık "... bir tümce yapısının şeyin yapısını yansıtıp yansitamadığıdır"(Heidegger, 2001, s. 23) Bu durum, Heidegger için Roma düşüncesinin Yunanı otantik uygunlukta çevir(e)memesinden ya da yorumlayamamasından kaynaklanır. Yansıtma anlayışı, yapıtın şeyliğini, yansıtılanın yansıttığıyla ilişkisinde görür; oysa Heidegger için yapıtın şeyselliğinin böyle bir ilişki içinde anlaşılması yeterli değildir; çünkü burada şeyin şey olma özelliği açığa çıkmaz. Şey'e ikinci yaklaşım, onu duyumlarla algılanabilir bir duyum algısı nesnesi olarak anlamaktır. $\mathrm{Bu}$ yaklaşımda şey, duyulara verilen çokluğun birleşiminden başka 
bir şey değildir. Ama bu yaklaşımda da şeyin kendisi kaybolmaktadır; çünkü soyut duyumlardan söz etmek olanaksızdır; ancak dünyaiçinde-bulunuşumuzla birlikte şeylerden ve onları oldukları şey kılan özelliklerden söz edebiliriz. Bu durumda herhangi bir nesnenin, o nesneden bağımsız olarak ortaya çıkabilecek özelliklerinden söz etmenin yolu kapanmış olmaktadır. Heidegger belirtilen tüm bu nedenler dolayısıyla şeyi aistheton (duyum) olarak anlamanın yetersiz kaldığını dile getirir. Şeyi özne-nesne temelli bir ikilik mantığı içinde anlayan her iki yaklaşım da estetik bir yaklaşım olarak şeyle yapıtın ilgisini kurmakta yetersiz kalır. Şey'e üçüncü yaklaşım ise, temelini Aristoteles'in metafiziğinde bulan madde (hule), biçim (form) ikiliğidir. Burada şey artık biçim kazanmış madde olarak anlaşılır. Heidegger'e göre “... madde biçim ayrımı neredeyse sanat kuramı ve estetiğin bütünü için, çok büyük değişikliklerle de olsa, kullanılan kavramsal bir şema olmuştur."(Heidegger, 2001, s. 27) Heidegger, estetik alanda madde-biçim ikiliği biçimindeki kavramsal çatının, sanatın doğasına içkin bir durum olarak anlaşıldığını ve bunun da doğaya aktarıldığını dile getirir. Böylece şeyin şey karakteri, hem sanat yapıtında hem de doğadaki şeylerin sıra-düzeninde madde-biçim ikiliği bağlamında görülmeye başlanır. Biçim bu durumda maddenin ereği olarak nesnenin ne için olduğunu, yani kullanılabilirliğini gündeme getirir. Bununla birlikte şey, kullanılabilirlik bağlamında tüketilebilir olan bir şey değildir; ama aynı zamanda yapıtın yapıtlı̆̆ 1 da yalnızca şeyle açıklanamaz. Sanat yapıtının kendine-yeter, kendi içinde-duran yapısı onu salt şey kılar. Bu anlamda yapıtın şeyliği, kullanılabilirlik anlamında oluştan farklıdır. O halde sanat yapıtı söz konusu olduğunda yapıtın yapıtlığını nasıl anlamak gerekmektedir? Heidegger, şeye ilişkin üç yaklaşımın ve bu yaklaşımların farklı biçimlerde oluşan türevlerinin ne yapıtın yapıtlı̆̆ını, ne şeyin yapısını, ne de yapıtın şeysel karakterini açımlayamadığını; bu konuda yetersiz kaldığını dile getirir. Bu noktada madde-biçim ilişkisinin oluşturduğu bir eksen etrafında sanat yapıtının salt şey oluşunun ne anlama gelebileceği düşünülür. Bu bağlamda Van Gogh'un "Köylü Pabuçları" adlı tablosu Heidegger'in sanat yapıtının kendi-içinde duran yapısına ışık tutması açısından önem taşır. Kendiiçinde duran, yani kullanışlılıktan, bir şey için olmaklıktan uzak duran bir yapı olarak söz konusu yapıtı yapıt kılan, onu diğer şey özelliği taşıyan nesnelerden ayıran temel özellik nedir? Bu temel özelliğin ne olduğunu yorumlarken Heidegger, gündelik yaşamla sanat yapıtını karşılaştırarak sanat yapıtının ayrıcalığını gösterir. Gündelik yaşamda dünya-içinde-oluş durumumuz nedeniyle olanlarla ilişkimiz hermeneutik, yani yorumsal bir biçimde gerçekleşir. Olanlarla ilişkimizin yorumsal biçimde olması, 
olanlarla ilişkimizin kullanılabilirlik ilişkisi içinde olmasıdır. Yani varolanlar olarak bizler bir şeyi hep başka bir şey için kullanırız. Gündelik yaşamın içinde süregelen bu ilişki, ilişkinin sürekliliği içinde kullanılan, ilişkiye geçilen aletlerin özelliklerinin kullanılabilirlikleri içinde kaybolmasına neden olur. Nesneler, oldukları şey haline kullanılışları bağlamında gelirler, ama kullanıla kullanıla oldukları şey halleri de kullanılışları içinde gözden kaçar. "Köylü Pabuçları" tablosundaki pabuçlara sahip olan bir kadının gündelik yaşam içinde bu pabuçların işlevi, anlamı üzerine düşünmesi pek de olası değildir. Köylü kadın, kendisine ait olan pabuçları düşünmeksizin giyer ve kullanır. Doğal olanı da budur, çünkü gündelik olanla ilişkimiz böyledir. Alet edevatın kullanım süreci içinde onların gündelik özellikleriyle karşılaşılmaz, bu özelliklerin ayırdına varılmaz. Gündelik yaşam, ilişkide olduğumuz şeyleri bizim için tanıdık kılar. Tanıdık kılınanda göze çarpıcı olan gözden kaybolur. Sanat yapıtının işlevi tam da bu noktada açığa çıkar. Heidegger'in yorumuna göre Van Gogh'un "Köylü Pabuçları" adlı yapıtı bir çift pabuç aracılığıyla bize o pabuçların ait olduğu dünyayı açar. Bir çift pabuç aracılığıyla açılan dünya, yeryüzüyle kurulan ilişkideki meşakkatin, bu mücadelede kendini duyuran kaygının, uğraşının sonucunda kazanılacak zaferin, yani köylü kadının dünyasıdır. Yapıt, gündelik yaşamın içinde sıradan, tanıdık hale gelen, üzeri örtülen bir dünyayı, bir çift pabuç aracılı̆̆ıyla açmakta; sıradan ve tanıdık olanı sıra-dışı bir biçimde göz önüne getirmektedir. Öyle ki ilk defa resim aracılığıyla gündelik yaşamın içinde anlamları sorgulanmayan pabuçların Varlığı, daha doğrusu varlığa gelişleri anlaşılır olmaktadır. "Sanat yapıtı pabuçların hakikatte ne olduğunu bilmemizi sağlamaktadır ... alet edevatın kullanılabilir olan doğası görünüşüne hakiki biçimde ilk defa yapıtla kavuşmaktadır." (Heidegger, 2001, s. 35) Van Gogh'un tablosu, Heidegger'e göre alet edevatın hakikatte ne olduğunu açmaktadır bize. Tabloda resmedilen nesne, varlığının açıklığında ortaya çıkmaktadır. Heidegger "açığa çıkma" derken Sokrates-öncesi dönemde kullanılan ve hakikat olarak çevrilen aletheia'yı kastetmektedir. Yani sanat yapıtında ele alınan nesne, neliği ve nasıllığı içinde örtüsünden sıyrılmakta, bir oluş olarak görünmekte, hakikatin olagelişi yapıtta işlemektedir.

Bir nesnenin hakikati sanat yapıtında kendini işlemeye koyar. Koymak duruşa gelmek demektir. Belli bir nesne, bir çift köylü pabucu, yapıtta varlığının ışığında durmaya gelir. Olanın varlığı, ışımasının sabitliği içine gelir (Heidegger, 2001, s. 35).

Heidegger böylece estetikte güzeli yansıttı̆̆ öne sürülen sanat 
yapıtının hakikati verdiğini, açtığını söylemiş olur. Mantığın alanına bırakılmış olan hakikatin, sanat yapıtında ortaya çıkması, beraberinde yapıtın bir gerçekliği temsil ettiği oranda hakikati dile getirmiş olabileceği türünden bir uygunluk kavrayışını akla getirir. Oysa burada metafizik geleneğin anladığı türden bir uygunluk anlayışıyla bağlantılı bir hakikat kavrayışı söz konusu değildir. Sanat yapıtı kendi dışındaki bir gerçekliğin, bu gerçekliğe olabildiğince uyan bir yeniden üretimi değildir. Tersine, gerçeklik denilen açığa gelme biçiminin de göz önüne getirildiği, gösterildiği bir işleyiş, bir oluş söz konusudur burada. Hakikatin kendini gösterdiği yer tam da sanat yapıtının kendisidir; dolayısıyla bu durumda hakikatin ne anlamı olduğu, işlevinin ve işleyişinin nasıl olduğu soruları ortaya çıkmakta, eş deyişle dünya kurmanın ve bu kuruluş sırasındaki savaşımın işleyişinin betimlenmesi gerekli olmaktadır.

\section{Dünya-Kurma / Yeryüzü İlişkisi}

Heidegger, sanatın kökeninin ne olduğuna ilişkin bir sorgulama geliştirirken ilkin modern bir sanat yapıtı üzerinden yapıtın temel özelliğine ulaşır. Sanat yapıtı bir dünyayı açar. Bir dünyayı açması o yapıtta hakikatin dile gelmesidir. Yapıtla hakikatin ilişkisi neden bu kadar önemlidir? Heidegger için yapıtın hakikatin olduğu yer olması, yapıtın modern sanatta açığa çıan gösterici işlevinden başka bir yönüne işaret eder. Bu, yapitın kuran, yaratan, oluşturan yönüdür. Heidegger, bunun örneğini bir Yunan tapınağında görür. Tapınak, kuruluşuyla birlikte bir merkez oluşturur. Bu merkez iki doğanın da merkezi gibidir. Tapınakla birlikte hem bir toplumun hem de tapınağın çevresindeki doğal alanın tarihselliği oluşmaya başlar. Tapınak durduğu yerde gökyüzünün derinliğini, kayaların sarplığını, bitki örtüsünün özelliklerini açığa çıkarır; eş deyişle, yapıyla birlikte phüsis görünür olur. Yapı aynı zamanda çevresinde bir sıra-düzeni koyar. Tapınakla birlikte tanrı, tanrının kutsal mihrabı, bu mihrap çevresinde düzenlenen kutsamalar ve kutlamalar gelişir. Bir halkı halk kılan, halkın dünyasını oluşturan kimi temel özellikler bu alanın etrafında biçimlenir. Böylece phüsis karşısında thesis de açığa çıkmış olur. Dünyanın ikili karakteri yapıt aracılı̆̆ıyla görünür olur: olanı açmak; yani uzam açmak ve ethos kurmak. Bu ikili örgü içinde yapıt ontolojik olanla etik olanı birleştiren bir merkez olarak düşünülür.

Tapınak orada durarak şeylere görünüşlerini, insanlara da kendilerine ilişkin bakışlarını verir. Bu görünüş, yapıt bir yapıt olarak kaldıkça, tanrı ondan kaçmadıkça açık kalır. Bu tanrının 
heykeli için de, adak sunusu için de, atletik oyunlardaki zaferler için de geçerlidir. Tapınak, tanrının nasıl göründüğünü daha kolay anlamamızı sağlayacak bir şey değildir; tanrının kendi olarak orada olmasını sağlayan bir yapıttır (Heidegger, 2001, s. 42).

İlk defa bir yapıtla birlikte olanın anlamı açılmakta, anlamı açılırken bir uzamlaşma, tarihselleşme, oluşumsallık başlamaktadır. Bu durum, yapıtları estetik bir nesne olarak gören kültür endüstrisinin ve estetik anlayışın gözden kaçırdığı bir noktadır. Bu nedenledir ki bir yapıt söz konusu olduğunda, dünyayla yapıt ilişkisi bir biçimde deformasyona uğramaktadır. Doğal ortamından, bağlamından kopartılan yapitın görsel bir sergi malzemesi olarak sunulmasıyla bağlamsızlaştırılan yapit, ait olmadığı bir ortamda artık hiçbir şeyi açamaz duruma gelerek kapanmaktadır. Bu tam da Heidegger'in tanrının tapınaktan kaçması dediği duruma karşılık gelmektedir. Bu durumda yapıt, dünyasından çekilmiş olur. Bir de yapıtın yüzyıllar içinden gelen tarihselliğinin artık bu dünyaya ait olmayan bir dünyayı dile getiren bir hakikate karşılık gelmesi vardır ki burada yapıt dünyasından değil, yapıtın ait olduğu dünya yapıttan çekilmiştir. Her iki durumda da bir çekilme vardır. Çekilmenin olması yapıtın salt bir nesne olarak görülmesinden kaynaklanır. Oysa yapıtta karşılaşılan bir dünyadır. Dünya da

\section{(...) orada duran sayılabilir ya da sayılamaz; tanıdık ya da tanımadık şeylerin salt bir koleksiyonu değildir (...) dünya asla önümüzde duran ve görülebilecek bir nesne değildir (...) dünya doğumun ve ölümün yolları, kutsama ve ilenç bizi Varlığa taşımaya devam ettiği sürece tabi olduğumuz daimi-nesnesel-olmayandır (Heidegger, 2001, s. 43).}

Dünyanın yapıt aracılığıyla açılması, dünyanın dünyasallaşması, aynı zamanda Heidegger'in yeryüzü dediği bir diğer önemli kavramı da devreye sokar. Burada dünyanın dünyasallaşması, tarihselleşmesi sürecinde açı̆̆a çıkan ikili yön, Heidegger'in özellikle vurguladığı ve polemos kavramı aracılığıyla açımlamaya çalıştığı yaratıcı ana süreci gösterir. Dünyanın olduğu şey haline geliş süreci hep bir temel üzerinde olur. Dünya yapıtın açtığı uzamdır. “... uzam Açıklığın serbest bırakılması ve yapısı içinde kurulmasıdır."(Heidegger, 2001, s. 44) Yapitın bir dünya açması ve bu açıklığı açık tutması, onun özelliklerinden yalnızca birisidir. Kurmak, oluşturmak aynı zamanda öne çıkarmak anlamına da gelmektedir. Bu süreçte kurulan dünya, öne getirilen de yeryüzüdür. Yapıt 
dünya ile yeryüzünün arasında bir tür merkez işlevi gören savaşımın başlatıcısı konumundadır. Yapıt bir dünya kurarken, yöneldiği maddenin de ilk defa yapıtın dünyasının açıklı̆ında öne gelmesini sağlamaktadır. Öyle ki ilk defa yapıtla birlikte, örneğin tapınakta olduğu gibi, taş, demir türünden doğaya ait nesneler oldukları şey haline gelmektedirler. Yapıt kendini maddeye, maddeyi biçimlendirmek için geri yansıtmakta ve ortaya kullanım amacına göre yapılar çıkmaktadır. Bu, dünyanın kendini yeryüzüne yansıtmasıdır. Bu yansıtma işinde, dünyayı kurmada yapıt böylece kurarken yeryüzünü öne çıkartmaktadır; yani ilk defa yapıtın işlemesiyle birlikte yeryüzü yeryüzü olarak oldurulduğu biçimiyle ortaya çıkmaktadır. Dünyayla yeryüzü arasındaki ilişki, sürekli bir savaşımın oluşa-geldiği, aletheia denilen ve içinde gizlenmeyle-saklanmayla, açığa çıkmanın birbirine bağlı bir biçimde süregeldiği bir ilişkidir. "Yeryüzünü öne çıkartmak demek, onu kendi-saklanışı içinde Açıklığa getirmek demektir."(Heidegger, 2001, s. 46) Heidegger yeryüzünün saklanışı derken onun dünyayla girdiği ilişkide gösterdiği çok-çeşitliliğe vurgu yapmaktadır. Yeryüzü değişmez bir öze sahip değildir; tersine kendini, ilişkiye girdiği oldurma biçimleri doğrultusunda birbirinden farklı olarak açabilmektedir. Bu durumda da hep başka biçimlerde açılabilen ve bir açılımıyla başka bir açılma olanağını gizli tutan, onun önüne geçen bir işleyiş olarak yeryüzü kendini hep gizli tutmuş olmaktadır. Bir Yunan tapınağıyla bir ortaçağ kilisesinin açarak kurmuş oldukları dünyalar birbirinden farklı dünyalardır. Farklı oluşları öne çıkardıkları yeryüzünün de farklı olması anlamına gelmektedir. "Yunanlılar, tapınakla açlan ve yoğunlaşan kılgılarını yaşamlarına yön ve anlam veren ahlaksal bir uzamda yaşarlar. Ortaçağ katedraliyse günahkârı ve azizi olanaklı kılarak Hıristiyanlara kurtuluşun ve lanetlenişin boyutlarını gösterir."(Dreyfus, 1993, s. 15) Yunan tapınağı çevresinde oluşmuş olan gökyüzünün ya da yerin anlamıyla bir katedralin çevresinde oluşmuş olan gökyüzü ve yerin anlamı birbirinden farklıdır; birinde öne çıkan öne çıktığı bağlam nedeniyle diğer bağlamın öne çık(a) maması demektir. Yeryüzünün özünde böyle bir ele geçirilemezlik vardır. Her farklı dünyada yeryüzü o dünyanın tarihselliği doğrultusunda kendisini açmakta ve böylece başka türden bir açılma olanağını da açıldığı tarihsellik bağlamında kapatmaktadır. Dünyayla yeryüzü arasındaki bu sürekli savaşımın hep yeryüzünün ele geçmezliğiyle sonuçlanması Heidegger'in aletheia olarak yorumladığı hakikatin ikili yapısından kaynaklanmaktadır. $\mathrm{Bu}$ hakikat bir tür gizlenmedir ve iki katmanlı bir işleyişe sahiptir. Yani ilkin açığa gelenin açığa geliş olarak açıklığa, bir saklanmışlıktan gelme anlamında çıkmış olduğundan söz edilebilir. $\mathrm{Bu}$, diyalektik ilişkinin konumlandırdığı bir açıklı kapalılık ilişkisi değildir. Açıklık demek 
zaten kapalılık demektir; çünkü bir şeyin açılması, açıklığa gelmesi demek onun açıklığa geldiği biçimiyle başka türden açığa geliş durumlarını, olanaklarını kapatmış olması demektir. Bu, kapanmanın, gizlenmenin ilk anlamıdır. Gizlenmenin ikinci anlamı ise, Heidegger' in ikili geri-çekilme olarak adlandırdığı açıklığın ikili yapısının da üstünün örtüldüğü ve varlığın unutuluşu olarak adlandırdığı devinimdir ki bununla birlikte hakikatin iki katmanlı işleyişi, yani yapısı dile getirilmektedir. Bu durumu Heidegger çoğu zaman yanlış anlamalara yol açan Hakikat, doğası gereği, hakikat-olmayandır aforizmasında dile getirir. Bu noktada dünyayı açılık, yeryüzünü de kapalı kalma olarak ve bu iki alan arasındaki savaşımı sanki birbirine karşıt, ayrı başına duran iki gücün çarpışması olarak düşünmek, Heidegger'in Varlığın hakikati olarak anladığı hakikati tam da onun karşı çıktığı bir biçimde diyalektik olarak okumak demektir. Oysa her iki güç de açıklığa aittirler. Dünya kurma, tarihselleşme Heidegger'in karar verme sözcüğünü kullanarak anlattı̆̆ bir süreçtir. Karar vermek ${ }^{1}$, ayırmaktır. "Her karar kendini hâkim olunamayan, saklayan, bulanıklaştıran birşeye dayandırır; yoksa bir karar olamazdı." (Heidegger, 2001, s. 53) Eş deyiş̧le karar açıklığa getirmenin, açığa çıkarmanın, savaşımın, bu çabanın adıdır. Herakleitos'un polemos'a ilişkin "savaşım her şeyin babasıdır" diye başlayan ünlü deyişi, bu savaşım sonucunda oluşan sıra-düzeni gösterir. Dünya ve yeryüzü, sonuç olarak birbirlerine aitliklerini çatışmac bir biçimde sergilerler. Bu, hakikatin yapıt aracılığıyla olagelişinden başka bir şey değildir. Dolayısıyla Heidegger için sanatın doğasını yapıtta kendini ortaya koyup işleyen hakikat olarak anlamak olanaklı görünmektedir. Heidegger, kadim Yunandaki anlamı anımsanacak olursa, artık ayrımlaşmış olmasına rağmen, yapıtın bir tekhne süreci sonucunda yaratılmış olduğunun özellikle altını çizmektedir. Bu nedenle de günümüzde anlaşıldığı anlamda sanat yapıtı olarak düşünülebilecek bir yapıtın, alet edevat örneğinde olduğu gibi, böyle düşünülemeyecek başka türden ama gene de bir tür yaratıya dayanan, örneklerden ayrı başına adlandırılması söz konusu değildir bu dönemde. Peki, o halde bir yaratıyı özel kılan Heidegger için ne olmaktadır?

Hakikatin yapıttaki kuruluşu, olanı daha önce hiç olmadığı ve tekrar hiç olmayacak biçimde öne getirmektir. Öne getirme, olanı Açıklığa öyle bir şekilde getirir ki öne gelen içinde öne geldiği Açıllı̆ın açıklı̆ını ilk defa açar. Yaratı işte böyle bir öne getirmedir. Böylesi bir öne getirme olarak yaratıcılık, açığa çıkartmayla bir alma ve bir birlik olma ilişkisidir (Heidegger, 2001, s. 60).

Heidegger entscheidung sözcügünün "kesmek" anlamına gelen scheidung köküne gönderme yapmaktadir. 
Heidegger, dünyayla yeryüzünün savaşımının merkezinde yer alan yapıtın, yaratıcılıkla olan bağlantısının bir tür yarılma/çatlama olarak düşünülebileceğini dile getirmektedir. Hakikat, dünya yeryüzü çatışması sürecinde yapıt olarak, yani yeryüzünün bilinmezliğinde, tanınmazlığında bir biçim kazanma olarak, eş deyişle bir yarılma olarak kendini oldurmaktadır. Bu, bir anlamda Kant'ı anımsatırcasına kendinde bilinmez olanın bir form bağlamında, bilince, bilincin formlarına göre, her ne kadar hep kendi-içinde bilinmez olarak kalacak olsa da, tanıdıklaştırılması gibidir. Savaşım bir tür yarılmaya neden olmakta, akışta kopma yaşanmakta, bu kopuşun sonucu bir biçimin ya da biçimler topluluğunun (geştalt) bir yerde sabitlenmesi olmaktadır. Özel türden bir yaratının tekhne'nin işleyişi sırasında oluşan diğer yaratılardan temel ayrımı daha önce de dile getirildiği gibi özel türden bir yaratıcılıkla ilgili olmasıdır. Bu türden bir yaratıcılıkta yaratı artık yeryüzünün öne çıkması olarak düşünülen ve kullanılışı içinde kaybolan bir yaratı değildir; tersine yeryüzünü bitimsiz açığa çıkışları bakımından olduğu biçimiyle ortaya çıkabilsin diye serbest bırakan bir yaratıdır. Bu noktada Heidegger için bir yapıtın yaratımında ne tek başına sanatçı, ne de alımlayıcı ön plana çıkar; o halde ön plana çıkan her iki tarafı da içine alan yapıtın kendisidir; çünkü yapıt aracılığıyladır ki sanatçının da içinde bulunduğu dünya açılmakta ve gene aynı yapıt aracılı̆̆ıyladır ki yapıtın açtığı hakikat kendini koruyan olarak alımlayıcıda koruna-durmaktadır. Bu durumda Heidegger için bir yapıtta yaratıcılıktan söz edilebilmesi için üçlü bir ilişkiden söz edilmelidir. İlkin yapıtın bir parçası olan yaratıcılık; yani bir dünya açma işlevi; ikinci olarak yapıtın burada, şimdide oluşu; üçüncü olarak da yapıtın yaratıcılığının korunuyor olması. Bunlar olmaksızın ayırıcı özelliği olan bir yapıttan söz etmek, Heidegger'e göre olanaklı görünmemektedir. Yaratıcılığın üçüncü öğesi olarak Heidegger' in özellikle vurguladığı korumanın önem taşıması teknolojinin belirlediği günümüz modern toplumuna yapılan bir eleştiri olarak okunabilir. Heidegger, yapitı korumayı "... yapıtta olagelen olanların açıklığında durmak" (Heidegger, 2001, s. 65) olarak düşünür. Bu da Heidegger için bilmektir; ama bilmek herhangi bir şey hakkında bilgi edinmek anlamına gelmez burada.

Bir isteme olarak kalan bilme ve bir bilme olarak kalan isteme varolan insan varlığının Varlığın açıklığına girişi ve onunla uyumudur (...) öznenin bilme eylemi, insanın içinde bulunduğu tutsaklıktan Varlığın açıklığına açılmasıdır (Heidegger, 2001, s. 65).

Teknoloji toplumu düşünüldügünde yapıtın korunması otantik olanı 
yakalamak anlamına gelmektedir. Yani modern toplumun kendini açma biçimi olarak teknolojinin görünümünün dayatmacı ve diğer açılımları kapatan tutumu, ancak büyük yapitların korunması aracılığıyla onlarda açığa çıkan dünyaların, hakikatlerin gösterdiğiyle karşılaşıldığında aşılma ya da kırılma olanağı taşıyabilir. Heidegger'in sanat yapıtı ve de yapit üzerinde durmasının nedeni onları bu kökensel dönüş olanağını bize açabilecek yapılar olarak düşünmesinde yatar. Bu tam da içinde yaşanılan çağın tanıdık kılarak üzerini örttüğü hakikatin salınımına maruz kalmayı istemek ve bu yolla da geçmişi tekrar tekrar ele geçirmeye çalışmaktır. Yapıtın ve sanat yapıtının ayrıksılığı da böyle bir isteği dayatan, ya da daha doğru bir ifadeyle, uyandıran kimi özellikleri taşıyor olmasından kaynaklanır. Bu bağlamda Heidegger sanat endüstrisinin sanat yapıtında açığa çıkan hakikatin yabancı ve tanımadık yüzünü tanıdık hale getirerek sanatı bir tür iş konumuna getirdiğini dile getirir. Böylece sanat modern dünyanın genel eğilimine uyumlulaştırılmış olur. Bu uyumlulaştırma işinde sanatın neyi dile getirdiği, ne olduğu ve neye kaynaklık ettiği de gözden kaçar.

Heidegger sanatı Varlığın anlamı dolayımında sorunsallaştırırken varmaya çalıştığ1 nokta hep kökenin ne olduğuydu. Burada köken kelimesinin de Almancada yapmış olduğu çağrışımı kullanır Heidegger. Bu bağlamda ursprung: ilksel atlama ya da temel atlama diye yorumlanır. Sanatın kökeninin ne olduğu sorusuyla ilişkisinde bakılan yer bu nedenle temelin yeridir; herşeyin kalkış noktası olan yerdir. Ancak temel olan ilksel bir atlamanın olmasıyladır ki söylenebilecek ya da kurulabilecek olanlar olanaklı hale gelir. Bu ilksel atlama sanattır; fakat sanattan anlaşılması gereken de ilksel anlamda yaratıcı olan dil, yani şiirdir.

\section{Dil-Yarat1-Şiir}

Hakikatin, Varlığın hakikati olması demek, Dasein'ın olanların olmasını atılmışlı̆̆ içinde kökenindeki yoksunluktan dolayı hep olana aşkın bir biçimde gerçekleştirmesi demektir. İçinde bulunulan açılığın, Heidegger için ileri dönük bir anlama biçiminde düşünülmesi ve Dasein'ı böyle bir tasarımsal anlayışla anlamak hakikatin tasarımsal-projektif olanla bağını açığa çıkarır; yani “... olanın açıklığı tasarlanmış, ileri yansıtılmış olarak ola-gelişini atılmışlıkta gerçekleştirir."(Heidegger, 2001, s. 69) Hakikatin oluşumsallığı, bu bağlamda dilin oluşturucu işleyişinden başka bir şey değildir. $\mathrm{Bu}$, sanat olarak anlaşılanın da kökeninde dil olduğunu söylemektir. Heidegger dil derken, gündelik iletişim anlamındaki dili 
değil; ama yaratıcı olan dili göz önünde tutar. Yaratıcı dil olarak temel poetik, yapıtta işleyen hakikate dayanan sanatçının ve sanat yapıtının kökeninde yatandır. Dil yaratıcıdır; çünkü ilk defa dille birlikte, olanlar açıklığa gelerek aydınlanırlar. Dilin olmadığ 1 yerde herhangi bir şeyin açıklığa gelmesi de söz konusu değildir.

Projektif söyleme şiirdir: dünyayla yeryüzünün ve onların savaşım alanının, böylece tanrıların yakınlığının ve uzaklığının yerinin söylenişidir. Şiir, olanın gizlenmişlikten açığa çıkışının söylenişidir. Gerçekleşen dil herhangi bir anda bir halkın dünyasının onun için tarihsel olarak ortaya çıtı̆̆ı ve yeryüzünün kapalı kalan olarak korunduğu bu söyleyişin oluşumudur (Heidegger, 2001, s. 71).

Heidegger'in yorumladığ 1 söyleyiş kökensel dil olmak bakımından taşıdığı yaratıcılıkla geniş anlamda mimariden şiire kadar sanatın tüm alanlarını kapsar. Kökensel dilin yaratıcı olmak bakımından temel olması olanların varlığa, açıklığa ilkin dil aracılığıyla gelmelerinden kaynaklanır. İşte bu nedenledir ki Heidegger dar anlamda poetik olanın, yani şiirin özel bir yere sahip olduğunu düşünür. Dil olanları olduran ilksel şiirdir; ama dar anlamda şiire yataklık etmesiyle de şiirin orijinal doğasını korumaktadır. Yaratıcı olması bakımından sanatın doğası poetiktir/ şiirseldir. Heidegger hakikatin kurulumu olarak şiirin doğasının üçlü bir işlevi olduğunu düşünür: o, bahşetme, verme olarak kurucudur; temellendirme olarak kurucudur; başlangıç olarak kurucudur. Bu aynı zamanda kurmanın her üç anlamda da şiiri, yaratıyı koruyucu kıldığını gösterir. Şiir, yapıtta işleyen hakikatin temeli olarak tanıdık olan içinde, üstü örtülen içinde o güne kadar görülmemiş olanı açar. Kendini açan hakikat, olan hiçbir şeyden çıkmaz. Daha önce ortaya çıkan ve sıradan olan şeyler, artık yapıtla birlikte eskiden olduğu gibi görül(e)mez olur. Yapıt böylece ayrıksı bir yaratı olarak olanın hakikatini o güne kadar olmadığı biçimde göstermiş olur. Bu, olana, ait olduğu hakikati vermektir; olanı hakikati içinde göstermektir; olana olmaklığını bahşetmektir. Böylece olana olanlığının verilmesiyle birlikte olanın hakikati yapıtta korunmuş olur. Şiir temellendirme, temel verme anlamında da kurucudur; çünkü her şeyden önce Heidegger için ölümlülerin yeryüzündeki duruşları poetiktir. Poetiktir; çünkü “... yaratmak eski Yunancada poiesis demektir."(Heidegger, 2001, s. 212). Yaratma, temel olmak anlamında ölçü vermedir. Ölçü ilk defa şairin diliyle verilir. Gökyüzü ile yeryüzü arasındaki uzanım bir ölçü olarak şairin dilinde oldurulur. Ölümlülerin yeryüzünü yuva edinmesi, onda temel bulması ilkin şairin gökyüzüne, 
olmakta olduğu şeyi vermesiyle olanaklı hale gelir. Böylece yeryüzü de, yuva edinilen yer olarak, üzerinde durulan yer olarak olduğu biçimde açığa gelir. Şair, söyleyişiyle uzamı açar; uzamın açılması temelin de oluşturulması anlamına gelir. Böylece şairin ölçü vererek oldurdukları şiirin dilinde otantik olarak orijinal-kökensel olarak tanınmadık bir biçimde korunarak kalır.

Ölçü şiirde verilir. Şiir yazmak, insanın ilk defa varlığın uzanımının ölçüsünü alması anlamında ölçü vermektir (Heidegger, 2001, s. 219).

Şairin şiirde ölçü vermesi bir halkı halk yapan sıra-düzenin kurulması anlamında temel oluşturmadır. Heidegger'e göre

... trajedide hiçbir şey teatral olarak sahneye konmaz; söz konusu olan, yeni tanrıların eski tanrılarla savaşıdır. Halkın dilinden çıkan dilsel yapıt, bu savaşa gönderme yapmaz; ama halkın söyleyişini öylesine dönüştürür ki şimdi her yaşayan sözcük savaşır ve halk, kutsal olanla olmayana, büyükle küçüğe, cesurla korkağa, yüce olanla alçak olana, efendi olanla köle olana karar vermeye katlanır (Heidegger, 2001, s. 42).

Kurucu olanın üçüncü anlamı olarak başlangıç, ilkel bir çekirdekten gelişmiş bir sonuca doğru gidiş süreci anlamında bir başlangıç değildir. Başlangıç, bir kesintisizliğin sürekliliğini değil kesilmelerin yarattığı kırılmaları ve kırılmalardaki ani geçişleri hazırlayan bir başlangıçtır. Başlangıç, aynı zamanda diğer iki kurucu özelliği kendinde toplayan ve böylece içinde tanıdık olanla olmayanın savaşımını başlatan sürecin adıdır. Savaşım, ölçü olarak verilenin zaman içinde kılık değiştirmesi, kendini saklaması biçiminde olagelişini, tanıdık, sıradan hale gelişi içinde üstü örtülerek görünmez olunanı tekrar tekrar ele geçirerek görünür hale getirecek atlamayı gerçekleştirmesi demektir. Bu bağlamda başlangıç, her zaman tanıdık olmayanın, sıra-dışı ve ayrıksı olanın açılımı olarak düşünülür. Başlangıç ilkin Yunan düşüncesiyle başlamış ve metafizik tarihini oluşturmuştur. Yunan düşüncesiyle başlayan metafizik tarihi, teknolojik açlmanın kapatan egemenliğine varmıştır. Her şeyin hesaplanabilirliğin sınırları içinde tanıdık kılındığı teknolojik açılım, Heidegger için her defasında yeniden yorumlanacak olan ve ilk ölçüyü veren başlangıca, kökene dönük bir atlamayı, sıçramayı da olanak olarak beraberinde taşır. Bu bağlamda başlangıcın ima ettiği koruma, yeniden ele geçirilecek olan varlığın anlamıdır. Ele geçirme, açılmayla kapanma; 
aydınlanmayla kararma; olmayla yok-olma arasındaki sürekli savaşımın da bir diğer adıdır ve bu savaşımın yeri olarak yapıtın neden Heidegger için bu kadar önem taşıdığı bu noktada açık hale gelmektir.

\section{Sonuç}

Tüm bu söylenenler bağlamında Heidegger' in bir sanat felsefesi yapmaya çalışmadığı açıktır. Yapmaya çalıştığı, varlığın anlamı sorusunu yapıt ve sanat yapıtı ekseninde ele alarak modern teknoloji biçiminde açlan ve başka türden her açılmanın önüne geçen açlım biçimine alternatif olanı göstermek ve böylece yeni bir düşünme biçiminin de önünü açmaya çalışmaktır. Böylece teknolojik dilin dışına çıkmak da olanaklı olacaktır. Sonuç olarak Heidegger'in varlıkbilimsel bir vurgu dolayımında kendini teknoloji olarak açan çağın temel eğilimi olarak metafiziği ve doğal olarak estetiği eleştirdiğini ve varlık merkezinde temellenen bir anlayış ekseninde şiirin, yaratıcılığın kökensel olan yapısını göstermeye çalıştığını söylemek olanaklıdır.

Emrah Akdeniz, Yüzüncü Yıl Üniversitesi, Türkiye

\section{Kaynakça}

Heidegger, Martin. (2001). Poetry-Language-Thought. Çev. Albert Hofstadler. New York, Perennial Classics.

Heidegger, Martin. (2001) Introduction to Metaphysics. Çev. Gregory Fried, Richard Polt. New Haven \& London, Yale University Press.

Young, Julian. (2001). Heidegger's Philosophy of Art. United Kingdom, Cambridge University Press.

Bossart, William H. (1968). Heidegger's Theory of Art. The Journal of Asthetics and Art Criticism. Vol. 27, No.1. ss.57-66.

Bruin, John. (1994). Heidegger and Two Kinds of Art. The Journal of Asthetics and Art

Criticism. Vol. 52, No. 4. ss. 447-57.

Dreyfus, Hubert L. (1993). Heidegger on the Connection between Nihilism, Art, Technology and Politics. The Cambridge Companion to Heidegger. Cambridge University Press. ss.289-316.

Hyland, Drew A. (1971). Art and the Happening of Truth: Reflections on the End of Philosophy. The Journal of Asthetics and art Criticism. Vol. 30, No. 2, ss.177-87. Krell, David Farrell. (1976). Art and Truth in Raging Discord: Heidegger and Nietzsche on the Will to Power. Boundary. 2, IV (2), ss. 379-92.

Mansbach, Abraham. (1997). Overcoming Anthropocentrism: Heidegger on the Heroic Role of the Works of Art. Ratio 10. Blackwell Publishers Ltd. ss.157-68.

Palmer, Daniel E. (1998). Heidegger and the Ontological Significance of the Work of Art. British Journal of Aesthetics. Vol. 38, No.4. ss. 394-411.

Stulberg, Robert B. (1973). Heidegger and the Origin of the Work of Art: An Explication. The Journal of Asthetics and Art Criticism. Vol. 32, No.2, ss. 257-65. 